PENDIDIKAN MULTIKULTURAL DI PULAU DEWATA (Sebuah Bunga Rampai tentang Pendidikan Multikultural Pada SMA di Provinsi Bali)

Penulis: A.M. Wibowo., dkk.

Editor: Mulyani Mudis Taruna

Layout dan Desain Cover: Musafak dan Muhammad Purbaya

Cetakan Pertama, Desember 2015

$16 \times 24 \mathrm{~cm}, 334 \mathrm{hlm}$.

ISBN: 978-602-7731-43-1

Penerbit:

CV. Arti Bumi Intaran

Mangkuyudan MJ III/216 - Yogyakarta

Telp./Facs.: (0274) 380228

email: artibumiintaran@gmail.com

ANGGOTA IKAPI

Perpustakaan Nasional: Katalog Dalam Terbitan (KDT)

hak cipta dilindungi undang-undang

isi di luar tanggungjawab percetakan 


\title{
PENDIDIKAN AGAMA BERWAWASAN MULTIKULTURAL PADA SMA SWASTA DI KABUPATEN KLUNGKUNG (Studi pada SMA Pariwisata Saraswati Kabupaten Klungkung)
}

\author{
Oleh \\ A.M. Wibowo
}

\section{PENDAHULUAN}

Salah satu persoalan yang dihadapi bangsa Indonesia ke depan adalah kehidupan antar umat beragama. Keyakinan keagamaan menempati posisi yang lebih tinggi dari ideologi. Oleh karena itu dalam perjalanannya sangat mungkin saling bersinggungan antara satu keyakinan dengan keyakinan yang lain.

Beberapa kasus kerusuhan yang mengatasnamakan agama terjadi di Indonesia akhir-akhir ini. Terakhir adalah peristiwa Tolikara di Papua yang berujung pada pembakaran tempat ibadah dan fasilitas umum yang lain. Peristiwa Tolikara mungkin hanya sebagian kecil peristiwa yang muncul dipermukaan. Jauh dari itu benih- benih perpecahan ada disekitar kita. Hal ini dimungkinkan karena kesadaran akan multikultural belum ditanamkan secara baik dalam dunia pendidikan maupun kehidupan sosial kemasyarakatan.

Agama adalah sesuatu yang sangat sakral, sehingga hampir tidak ada seorangpun yang tidak emosional ketika berbicara masalah agama, apalagi agama yang dianutnya menjadi trending topic dalam berbagai media 
karena ada sebagian kecil umatnya yang tidak seirama dengan kebanyakan. Agama juga menjadi sangat dibutuhkan ketika manusia berada dalam kehampaan spiritual dan pada saat yang sama mengalami kebuntuan dalam berbagai persoalan hidup dan kehidupan. Di sinilah agama menjadi sangat penting keberadaannya sehingga tidak akan hilang dari kehidupan manusia yang sebenarnya, meskipun ada sebagian kecil yang menjadikan agama sebagai simbol agar dapat diterima di masyarakat. Agama adalah realitas sosial yang di dalamnya tidak hanya terkandung ajaran yang bersifat normative doctrinal melainkan juga terdapat variabel pemeluk, tafsir ajaran, lembaga keagamaan, tempat suci serta bangunan ideologi yang dibangun dan dibela oleh para pemeluknya.

Indonesia sebagai negara yang majemuk, baik dari aspek suku, ras, maupun agama membutuhkan kerangka khusus untuk menciptakan keutuhan bersama dalam kehidupan berbangsa dan bernegara. Dalam konteks ini, Pemerintah telah menciptakan visi kehidupan beragama yang dikenal dengan tri kerukunan hidup beragama yaitu kerukunan intern umat seagama, antarumat beragama, serta antara umat beragama dengan pemerintah. Visi ini menjadi penting karena dalam ajaran agama pada satu sisi mengedepankan cinta kasih, mengajarkan keramahan, kesejukan, dan kebaikan-kebaikan untuk umat yang tidak seagama, namun disisi lain agama juga dapat mendorong penganutnya bersifat egois, keras, dan tegas kepada penganut agama yang lain. Hal ini dikarenakan beragama berarti harus memegang teguh ajaran agamanya dan membenarkan ajaran agamanya.

Terkait dengan pengembangan kewarganegaan dan pengembangan kebudayaan, bangsa Indonesia ditakdirkan sebagai sebuah bangsa dengan corak masyarakat yang plural. Pluralitas masyarakat Indonesia ditandai dengan kenyataan adanya ikatan-ikatan sosial yang berdasarkan perbedaan suku bangsa, agama, adat serta kedaerahan.

Semboyan Bhineka Tunggal Ika yang bermakna berbeda-beda tetapi satu kesatuan merupakan sebuah konsep kekuatan untuk menyadarkan 
bahwa kemajemukan yang dimiliki Indonesia memiliki dua potensi sekaligus. Dua potensi tersebut adalah persatuan (integratif) dan perpecahan (disintegratif). Sebuah kenyataan bahwa bentuk negara kita yang berbentuk kepulauan yang terdiri dari berbagai suku etnik, budaya, bahasa, serta agama dan tersebar pada pulau-pulau di Indonesia. Tercatat lebih dari 300 kelompok etnik di negara Indonesia.

Dilihat dari jumlah varian agama, meskipun Pemerintah Indonesia saat ini secara administrative hanya melayani (mengakui) enam agama terbesar di Indonesia (Islam, Kristen, Katholik, Hindu, Budha dan Khong $\mathrm{Hu} \mathrm{Cu}$ ) namun sebenarnya ada banyak varian agama yang tumbuh subur di Indonesia seperti Kaharingan, Sunda Wiwitan, Subud, Pangestu dan lain sebagainya.

Selama sejarah Nusantara, etnik-etnik di Indonesia mempertahankan identitas masing-masing, selain karena tempat-tempat yang terpisah secara geografis, juga karena adanya pengaruh berbagai faktor sosial, budaya, politik, ekonomi, dan sebagainya. Dalam bahasa psikologi sosial, etnik-etnik yang terpisah secara geografis dan sosial budaya yang berbeda, mempunyai dan mengembangkan pengalaman psikologis masing-masing, yang pada gilirannya menghasilkan identitas etnik masing-masing juga. Keterikatan pada identitas etnik akan menimbulkan saling prasangka antaretnik yang bisa menghambat proses akulturasi bangsa (Sarwono, 2007:31).

Diantara sekian banyak hal yang dianggap pemicu konflik pada masyarakat majemuk di Indonesia adalah masalah kebudayaan antar suku, agama dan ekonomi. Perbedaan kebudayaan atau agama memang potensial untuk mendestabilkan negara-bangsa. Karena memang terdapat perbedaan dalam orientasi dan cara memandang kehidupan ini, sistem nilai yang tidak sama, dan agama yang dianut masing-masing juga berlainan. Perbedaan di dalam dirinya melekat (inherent) potensi pertentangan, suatu konflik yang tersembunyi (covert conflict) (Nasikun 1985).

Sikap etonosentris dalam masyarakat majemuk sering diikuti oleh stereotip etnik yaitu pandangan umum suatu kelompok etnis yang 
menganggap kelompoknya lebih baik daripada etnis lain (Horton \& Hunt: 1984:65). Beberapa contoh bentuk disintegratif akibat primodialisme, stereotype etnik sebagai akibat etnosentrisme antara lain konflik Dayak dan Madura di Kalimantan (Republika February 2001), Konflik Jawa dan Aceh tahun 1975-2005 (Kompasiana 2014), konflik Papua, serta konflik Lampung yang melibatkan suku Bali dan Suku Lampung (Kompas Oktober 2012) dan lain sebagainya. Konflikkonflik tersebut merupakan bentuk kurang terbinanya multikultural di Indonesia.

Fungsi pendidikan nasional sebagaimana dalam Undang-Undang Sisdiknas No 20 tahun 2003 disebutkan dalam Bab II pasal 3 yaitu mengembangkan kemampuan dan membentuk watak serta peradaban bangsa yang bermartabat dalam rangka mencerdaskan kehidupan bangsa. Membentuk watak serta peradaban bangsa yang bermartabat artinya adalah pendidikan di Indonesia difungsikan sebagai pengembangan kepribadian, pengembangan kewarganegara-an, dan pengembangan kebudayaan.

Pendidikan agama di sekolah sebagai salah satu mata pelajaran pada lembaga pendidikan formal sekolah memiliki peran strategis dalam usaha menanamkan pendidikan multikultural pada peserta didik. Namun menjadi sebuah pertanyaan besar bagi kita apakah prinsipprinsip pendidikan serta fungsi pendidikan sebagaimana tercantum dalam UU No 20 tahun 2003 tentang Sistem Pendidikan Nasional telah terimplementasi pada tataran praktis di lembaga-lembaga pendidikan formal di Indonesia.

Penelitian ini mengambil fokus pada pendidikan agama berwawasan multikultural pada sekolah swasta di propinsi Bali. Propinsi Bali memiliki keunikan dan keunggulan kebudayaan yang menarik pendatang untuk menetap dan mencari pekerjaan di propinsi ini. Sebagai konsekuensi daerah tujuan wisata, wisatawan manca negara dan domestik, maka mobilitas penduduk (migrasi) akan selalu terjadi di Bali. Fakta yang ada menunjukkan jumlah "kaum pendatang", khususnya etnis Nusantara cukup besar di Bali. Menurut data dari 
Badan Informasi dan Telematika Propinsi Daerah Bali tahun 2004 ada 22 jumlah paguyuban etnis Nusantara (Geriya, 2004).

Banyaknya suku bangsa yang saat ini mendiami propinsi Bali jika tidak dikelola dengan baik akan menimbulkan potensi konflik yang besar baik atas nama agama, budaya, maupun ekonomi. Oleh karenanya, penelitian tentang pendidikan agama berwawasan multikultural menjadi penting dilakukan di SMA dalam rangka melakukan pemetaan terhadap pendidikan multikultural melalui pendidikan agama.

Multikulturalisme" pada dasarnya adalah pandangan dunia yang kemudian dapat diterjemahkan dalam berbagai kebijakan kebudayaan yang menekankan penerimaan terhadap realitas keagamaan, pluralitas, dan multikultural yang terdapat dalam kehidupan masyarakat. Multikulturalisme dapat juga dipahami sebagai pandangan dunia yang kemudian diwujudkan dalam kesadaran politik (Azra, 2007).

Multikulturalisme adalah sebuah fakta, fakta semakin bercampur baurnya penduduk dunia yang mampu memberikan tekanan pada sistem pemerintahan, pendidikan, dan ekonomi yang telah mapan untuk berubah (Baidhawy, 2005:1). Multikulturalisme mencakup suatu pemahaman, penghargaan serta penilaian atas budaya seseorang, serta suatu penghormatan dan keingintahuan tentang budaya etnis orang lain (Lawrence Blum, dikutip Lubis, 2006:174). Multikultural sebuah ideologi yang mengakui dan mengagungkan perbedaan dalam kesederajatan baik secara individual maupun secara kebudayaan (Suparlan, 2002, merangkum Fay 2006, Jari dan Jary 1991, Watson 2000).

Pendidikan multikultural adalah merupakan suatu gerakan pembaharuan dan proses untuk menciptakan lingkungan pendidikan yang setara untuk seluruh siswa (Arifin, 2012:74). Zakiyudin Baidhawy dalam buku Pendidikan Agama berwawasan Multikultural (2005) menyebutkan bahwa pendidikan multikultural adalah suatu cara mengajarkan keragamaan (teaching diversity). Pendidikan multikultural menghendaki rasionalisasi etis, intelektual, sosial dan pragmatis secara 
inter-relatif yaitu mengajarkan ideal-ideal inklusivisme, pluralism, dan saling menghargai semua orang dan kebudayaanmerupakan imperative bumanistic yang menjadi prasyarat bagi kehidupan etis dan partisipasi sipil secara penuh dalam demokrasi multikultural dan dunia manusia yang beragam. (2005:8).

Dimensi Pendidikan Multikultural menurut James A. Banks (2002:14), terdiri dari lima dimensi. Pertama, content integration, yaitu sebuah usaha yang dilakukan guru untuk memberikan pembelajaran dengan mengintegrasikan nilai-nilai budaya dan agama dari berbagai kebudayaan dan agama yang ada. Secara khusus, para guru menggabungkan kandungan materi pembelajaran ke dalam kurikulum dengan beberapa cara pandang yang beragam. Kedua, knowledge construction, yaitu suatu dimensi yang menggambarkan keaktifan guru dalam membantu peserta didik dalam memahami, menyelidiki, dan menentukan bagaimana asumsi budaya serta agama implicit serta mengajarkan bagaimana bersikap pada masyarakat yang multikultural. Ketiga, dimensi prejudice reduction, yaitu kegiatan yang dilakukan oleh guru dalam usaha membantu siswa untuk mengembangkan sikap rasial yang positif dan demokratis. Keempat, dimensi equitable pedagogy, yaitu modifikasi startegi mengajar guru dalam mengimplementasikan pendidikan multikultural di dalam kelas. Kelima, dimensi empowering school culture and social structure, yaitu memberdayakan budaya siswa yang dibawa ke sekolah yang berasal dari kelompok yang berbeda.

Berangkat dari pendahuluan dan kerangka teori tersebut di atas penelitian ini merumuskan 4 pertanyaan penelitian yaitu apakah budaya sekolah turut mendukung Implementasi pendidikan agama berwawasan multikultural pada SMA swasta di Provinsi Bali, apakah kurikulum pendidikan agama di sekolah di desain atau memasukan nilai-nilai multikultural? bagaimanakah presepsi siswa SMA terhadap hasil pembelajaran pendidikan agama berwawasan multikultural, dan, bagaimana Pendukung dan Penghambat implementasi pendidikan agama berwawasan multikultural pada SMA swasta di Provinsi Bali? 
Berangkat dari rumusan masalah tersebut maka tujuan penelitian ini adalah pertama, mendeskripsikan budaya sekolah dalam mendukung implementasi pendidikan agama berwawasan multikultural pada SMA swasta di Provinsi Bali. Kedua, mendeskripsikan pemahaman guru agama dalam menyusun kurikulum pendidikan agama berwawasan multikultural pada SMA swasta di Propinsi Bali. Ketiga, mendeskripsikan presespsi siswa sebagai evaluasi terhadap hasil pembelajaran pendidikan agama berwawasan multikultural. Keempat, mendeskripsikan faktor pendukung dan penghambat dalam implementasi pendidikan agama berwawasan multikultural pada SMA di Propinsi Bali.

\section{METODE PENELITIAN}

Penelitian ini dilakukan pada tahun 2015 dan membutuhkan waktu selama 4 bulan, yaitu Januari-April. Metode penelitian yang digunakan dalam penelitian ini adalah kualitatif yang diartikan sebagai metode penelitian berlandaskan pada filsafat post positivisme/enterpretif. Metode ini digunakan untuk meneliti pada kondisi subyek implementasi pendidikan agama berbasis multikultural pada SMA di Propinsi Bali. Peneliti adalah sebagai instrumen kunci (Bogdan, 1982). Peneliti mencoba melihat kurikulum pendidikan agama, proses pembelajaran, budaya sekolah, presepsi siswa, dan faktor yang mempengaruhi pendidikan agama berwawasan multikultural di SMA.

Subyek penelitian ini adalah SMA swasta yang ada di Kabupaten Klungkung Propinsi Bali. Hasil studi pendahuluan diperoleh subyek penelitian SMA Pariswisata Saraswati . Di SMA ini hidup lebih dari satu agama dan peserta didiknya terdiri dari berbagai macam etnis seperti Bali, Jawa, Sunda, Sumatra dan Madura.

Teknik pengumpulan data dalam penelitian ini meliputi wawancara, observasi, studi dokumen, dan kuesioner. Penggunaan kuesioner dipergunakan untuk mengetahui sikap pernyataan peserta didik terhadap contoh-contoh kasus-kasus yang diberikan. Kuesioner berisi 
pernyataan-pernyataan yang berhubungan dengan multikulturalisme dan pluralism dalam kehidupan beragama. Skala pengukuran yang digunakan adalah skala sikap.

\section{TEMUAN PENELITIAN}

\section{Selayang Pandang Kabupaten Klungkung}

Kabupaten Klungkung merupakan Kabupaten yang paling kecil dari 9 (sembilan) Kabupaten dan Kodya di Propinsi Bali. Kabupaten ini berbatasan dengan Kabupaten Bangli di sebelah utara, Kabupaten Karangasem di sebelah Timur, Kabupaten Gianyar disebelah Barat, dan Samudra India di sebelah Selatan, dengan luas: $315 \mathrm{Km}^{2}$.

SMA Pariwisata Saraswati adalah satu diantara 18 buah SMA di kabupaten Klungkung. Sekolah ini dikelola oleh Yayasan Perguruan Rakyat Saraswati . Yaitu sebuah yayasan yang mengelola pendidikan terbesar di propinsi Bali. Yayasan Perguruan Rakyat Saraswati mengelola pendidikan mulai dari taman Kanak-kanak hingga perguruan tinggi. Sekolah-sekolah di bawah pengelolaan yayasan Satraswati tersebar di seluruh wilayah di Propinsi Bali.

Visi sekolah ini adalah Menjadikan SMA Pariwisata Saraswati Klungkung sebagai lembaga pendidikan yang favorit dan dicintai oleh masyarakat, unggul dalam mutu, sehingga mampu menghasilkan tamatan yang kredibel, berahlak, berpengetahuan dan berketrampilan yang berlandaskan budaya bangsa. Misi yang diemban oleh SMA Pariwisata Saraswati ada 3 yaitu pertama, melaksanakan kegiatan pembelajaran dan bimbingan secara terjadwal dan efektif sehingga setiap siswa dapat berkembang secara optimal sesuai potensi yang dimiliki; kedua, mensosialisasikan dan menumbuhkan semangat keunggulan dan kompetitif secara intensif kepada seluruh warga sekolah; dan ketiga, membina siswa melalui jalur-jalur pembinaan kesiswaan untuk menghasilkan pribadi-pribadi yang bertaqwa terhadap Tuhan Yang Maha Esa, berbudi pekerti luhur, menguasai ilmu dan keterampilan serta cinta tanah air dan bangsanya. 


\section{Komponen pendidikan SMA Pariwisata Saraswati}

\section{Tenaga pendidik}

Jumlah tenaga pendidik yang mengajar di SMA Saraswati secara keseluruhan berjumlah 59 orang. Dilihat dari asal daerah tenaga pendidik dari dari 59 orang guru hanya dua orang yang bukan berasal dari daerah Bali. Dua orang guru tersebut berasal dari Banyuwangi Jawa Timur.

Dilihat dari agama yang dianut tenaga pendidik dari 59 orang guru hanya dua orang yang memeluk agama Islam, selebihnya beragama Hindu. Dua orang guru beragama Islam tersebut merupakan guru PNS yang membantu mengajar di SMA Saraswati . Di SMA ini tidak terdapat guru yang agama selain Hindu dan Islam dikarenakan tidak ada peserta didik yang menganut agama selain Hindu dan Islam. Jumlah guru agama yang mengajar di SMA ini berjumlah 4 orang, yaitu 3 orang guru agama Hindu dan1orang guru agama Islam.

Sekolah berupaya menjalankan tradisi keagamaan Hindu Bali secara utuh. Tradisi keagamaan yang dimaksud berupa doa bersama atau Trisandya setiap pagi yaitu mulai pikul 07.15 sampai dengan 07.30 waktu setempat. Kegiatan doa bersama (trisandya) ini dilakukan setiap hari di lapangan dengan mengumpulkan seluruh siswa dikumpulkan di lapangan upacara termasuk siswa yang beraga Islam. Peserta didik beragama Islam tetap diminta untuk ke lapangan upacara oleh pihak sekolah dan dipersilahkan untuk berdoa menurut agama Islam

\section{Tenaga Kependidikan}

Secara keseluruhan jumlah tenaga kependidikan di SMA Pariwisata Saraswati berjumlah 8 orang. Keseluruhan tenaga kependidikan ini adalah berasal dari Bali dan tinggal di sekitar Kabupaten Klungkung. Ada alasan mengapa pihak yayasan atau sekolah tidak mengambil tenaga kependidikan dari luar etnis Bali. Ini dikarenakan gaji yang diterimakan kepada tenaga kependidikan relative tidak besar. 
Dilihat dari komposisi berdasarkan jenis kelamin, jumlah tenaga kependidikan yang bekerja di SMA ini hampir berimbang, yaitu 5 orang laki-laki dan 3 orang perempuan. Seluruh tenaga kependidikan yang bekerja di SMA Pariwisata Saraswati berpendidikan SMA.

\section{Peserta didik}

Peserta didik yang menuntut ilmu di SMA Saraswati secara keseluruhan berjumlah 961 orang. Dilihat dari agama yang dipeluk oleh peserta didik hampir seluruh peserta didik yang belajar di SMA ini beragama Hindu Bali. Hanya 13 orang saja yang beragama Islam. Dilihat dari keasalan siswa seluruh peserta didik yang beragama Hindu di sekolah ini adalah berasal dari etnis Bali dari berbagai kasta. Sedangkan siswa yang beragama Islam di sekolah ini sebagian besar berasal dari pernikahan campuran antar etnis seperti Jawa dan Bali, Sunda dan Bali, Sumatra dan Bali, Madura dan Bali. Tionghoa dan Jawa, Jawa dengan Jawa. Namun demikian, peserta didik muslim di sekolah ini ada yang berasal dari etnis Bali.

Dari data yang diperoleh terungkap bahwa rata-rata peserta didik muslim dari hasil perkawinan antar etnis orang tua laki-laki (ayah) berasal dari luar Bali dan orang tua perempuan (ibu) berasal dari etnis Bali yang kemudian memeluk Islam. Berikut ini akan disajikan tabel komposisi peserta didik dilihat dari agama yang dipeluknya.

Tabel 1 Komposisi Peserta Didik Dilihat dari Agama yang Dipeluk

\begin{tabular}{|l|l|c|c|c|}
\hline \multirow{2}{*}{ No } & \multirow{2}{|c|}{ Data Siswa } & \multicolumn{2}{|c|}{ Agama } & \multirow{2}{*}{ Jumah } \\
\cline { 3 - 4 } & & Hindu & Islam & \\
\hline 1 & Kelas X & 336 & 9 & 345 \\
\hline 2 & Kelas XI & 332 & 2 & 334 \\
\hline 3 & Kelas XII & 280 & 2 & 282 \\
\hline
\end{tabular}

Dari tabel di atas terungkap bahwa siswa muslim terbanyak ada di kelas X, yaitu berjumlah 9 orang. Patut disayangkan seluruh siswa muslim pada masing-masing tingkat tidak menjadi satu. Tidak menjadi satu ini dikarenakan peserta didik telah memilih program peminatan sejak di kelas X yaitu peminatan IPA, IPS, dan Bahasa. 


\section{Sarana dan Prasarana pendidikan}

Bangunan yang dimiliki SMA Pariwisata Saraswati Klungkung terdiri dari 2 gedung yaitu gedung Barat 2 lantai, gedung sebelah Selatan 3 lantai. Sarana dan prasarana secara umum meliputi ruang belajar, ruang laboratorium, bimbingan konseling, ruang praktik, ruang kantor, serta sarana lainnya. SMA Pariwisata Saraswati Klungkung mempunyai Ruang kantor yang terdiri dari Ruang Kepala Sekolah, Ruang Tamu, Ruang Wakil Kepala Sekolah, Ruang Guru dan Ruang Tata Usaha.

Untuk belajar, SMA Saraswati telah menyediakan 24 ruang kelas sebagai sarana dalam proses kegiatan belajar mengajar di kelas. Dari 24 ruangan belajar tersebut saat ini sudah 23 ruang belajar yang dipergunakan, sedangkan satu ruangan dipergunakan sebagai cadangan ruangan.

Sebagai sarana penguat keimanan peserta didik dan seluruh komponen sekolah maka dibutuhkan sarana peribadatan. SMA Pariwisata Saraswati memiliki sarana peribadatan yang bersifat tetap dan sarana peribadatan yang dapat dibongkar pasang. Sarana peribadatan yang bersifat tetap berupa lapangan upacara dan Padmasana. Lapangan upacara di SMA ini setiap hari dipergunakan untuk bersembahyang atau mengucapkan Trisandya. Setiap pukul 07.15-07.30 waktu setempat lapangan ini selalu dipadati oleh seluruh siswa dan guru, baik Hindu maupun non Hindu. Bagi mereka yang non Hindu diwajibkan untuk hadir dilapangan namun berdoa sesuai dengan agama dan kepercayaan masing-masing.

Sarana peribadatan yang bersifat tetap lainnya adalah Padmasana yaitu sebuah bangunan peribadatan yang dipergunakan oleh pemeluk agama Hindu untuk bersembahyang baik ketika Trisandya maupun ketika upacara Purnama dan Tilem. Bangunan ini terletak di bagian Timur Laut (Kaja Kangin) sekolah yang merupakan arah suci bagi umat Hindu. Tempat ini digunakana oleh seluruh warga sekolah (khusus umat Hindu) untuk memohon keselamatan, perlindungan dan lain-lain. 
Kegiatan sembahyang dilakukan setiap hari, dan pada hari-hari suci seperti Saraswati, Purnama, Tilem, dan hari-hari raya lainnya

Sarana peribadatan lainnya adalah sarana peribadatan yang dapat di bongkar pasang. Sarana ini berupa bangunan berukuran 3X4 m yang terletak di lantai satu bekas perpustakaan yang sekarang dipergunakan sebagai gudang. Sarana peribadatan tersebut dapat dibongkar pasang karena hanya dibatasi oleh gorden.

Ruangan ini pada awalnya dipergunakan sebagai tempat beribadah peserta didik yang beragama Islam untuk menunaikan salat. Namun, menurut kepala SMA sarana ini sejak November 2014 tidak dipergunakan lagi setelah digunakan untuk kegiatan lomba Kelompok Siswa Peduli Aids dan Narkoba (KSPAN). Saat ini ruangan ini tak lebih hanya sebagai gudang penyimpanan barang-barang milik sekolah.

"Kami punya peralatan sembahyang untuk mereka yang muslim, dari mulai mukena sampai sajadah, namun saya lihat anak-anak yang Islam tidak pernah lagi menggunakan tempat ini lagi jadi tempat ini untuk sementara waktu kami bongkar," tutur kepala SMA $^{1}$

Komponen sarana dan prasarana lainnya adalah kantin sekolah. Kantin sekolah merupakan tempat istirahat bagi peserta didik yang hendak membeli makanan dan minuman dikala jam istirahat. Kantin sekolah yang terdapat pada SMA Pariwisata Sarawati mengakomodir peserta didikyang beragama non Hindu/ Islam. Seluruh makanan di kantin ini tidak menggunakan daging babi dan sapi sebagai menu makanannya. Lauk yang dihidangkan di sini berupa gorengan dan daging ayam. Disamping itu, salah satu penjual makanan di kantin ini adalah seorang muslim. Ia menjual bakso ayam sebagai dagangan utamanya.

Kepala SMA Pariwisata Saraswati mengungkapkan bahwa ia berusaha agar seluruh peserta didik disini dapat beristirahat makan tanpa perlu takut memilih makanan yang akan dipilihnya apakah

${ }^{1}$ Wawancara dengan Kepala SMA Pariwisata Saraswati, Maret 2015 
diperbolehkan menurut agama atau tidak. Hal tersebut dilakukannya agar siswa tidak jajan di luar sekolah karena makanan bagi mereka yang muslim ada di sekolah ini.

\section{Komponen Kurikulum}

Kurikulum yang berlaku di SMA Pariwisata Saraswati adalah kurikulum KTSP. Kurikulum SMA Pariwisata Saraswati Klungkung dikembangkan sesuai dengan analisis konteks atas dukungan komite sekolah di bawah koordinasi dan supervisi Dinas Pendidikan Pemuda dan Olah Raga Kabupaten Klungkung dan Dinas Pendidikan Pemuda dan Olah Raga Provinsi Bali, dan berpedoman pada SI dan SKL serta panduan penyusunan kurikulum yang disusun oleh BSNP. Kurikulum SMA Pariwisata Saraswati Klungkung dikembangkan berdasarkan prinsip-prinsip berpusat pada potensi, perkembangan, kebutuhan, dan kepentingan peserta didik dan lingkungannya, yaitu dikembangkan berdasarkan prinsip bahwa peserta didik memiliki posisi sentral untuk mengembangkan kompetensinya agar menjadi manusia yang beriman dan bertakwa kepada Tuhan Yang Maha Esa, berakhlak mulia, sehat, berilmu, cakap, kreatif, mandiri dan menjadi warga negara yang demokratis serta bertanggung jawab.

\section{Kurikulum Pendidikan Agama Hindu dan Kegiatan Belajar Mengajar}

Kurikulum mata pelajaran pendidikan agama Hindu SMA Pariwisata Saraswati menggunakan Kurikulum Tingkat Satuan Pendidikan. Jam pembelajaran pendidikan agama Hindu di sekolah ini adalah 2 jam pelajaran dengan asumsi 1 jam pelajaran adalah 45 menit. Selama 2 jam pelajaran tersebut guru agama menyampaikan materimateri yang telah dipersiapkan dalam rencana pelaksanaan pembelajaran.

Rencana pelaksanaan pembelajaran meliputi standar kompetensi dan kompetensi dasar yang harus dikuasai siswa, indikator pembelajaran, tujuan pembelajaran, materi pokok, serta metode pembelajaran yang dianggap tepat untuk menjelaskan standar 
kompetensi. Dalam observasi di kelas XII, langkah-langkah pembelajaran meliputi kegiatan apresepsi, kegiatan inti, dan penutup.

Kegiatan apresepsi guru dan siswa mengucapkan salam panganjali umat dan dilanjutkan dengan melaksanakan puja Trisandya. Kegiatan ini dilanjutkan dengan memaparkan tujuan pembelajaran yang harus dicapai pada pertemuan tersebut. Siswa kemudian diarahkan untuk membentuk kelompok diskusi. ${ }^{2}$

Pada kegiatan inti, guru melakukan tiga tahapan yaitu eksplorasi, elaborasi, dan konfirmasi. Pada kegiatan Eksplorasi, guru menugaskan siswa mencari dan menemukan informasi tentang materi pembelajaran pada hari itu contoh tentang pengertian moksa, ciri-ciri Moksa, tingkatan Moksa, dan pengertian masing-masing tingkatan Moksa serta mendiskusikannya dengan teman kelompok. Setelah melakukan eksplorasi bersama kelompok, kemudian guru melakukan tahapan elaborasi. Pada tahap ini, guru menugaskan siswa untuk mempresentasikan informasi yang diperoleh dari materi yang telah dibagikan secara berkelompok. Pada tahap konfirmasi, guru mengadakan penilaian secara berkelompok dan menjelaskan kembali materi tersebut penting sebagai bentuk review kepada peserta didik agar lebih jelas.

Suasana sama ditemui pada pembelajaran agama Hindu pada kelas X Suasana pembelajaran pada kelas ini meliputi kegiatan apresespsi, kegiatan inti, dan kegiatan penutup. Kegiatan apresepsi meliputi kegiatan pengucapan salam panganjali umat (ohm swastiathu) dan dilanjutkan dengan memaparkan tujuan pembelajaran yang harus dicapai pada pertemuan tersebut.

Pada kegiatan inti, guru melakukan tiga tahapan yaitu eksplorasi, elaborasi, dan konfirmasi. Pada kegiatan Eksplorasi, guru menugaskan siswa mencari dan menemukan informasi tentang materi pembelajaran pada hari itu. Setelah melakukan eksplorasi bersama kelompok kemudian guru melakukan tahapan elaborasi yaitu berdiskusi dengan peserta didik terkait dengan materi yang disampaikan.

\footnotetext{
${ }^{2}$ Observasi di kelas XII IPB
} 
Kegiatan belajar mengajar (KBM) pada mata pelajaran agama Hindu menempati ruang kelas. Hal ini dikarenakan mayoritas peserta didik di SMA adalah beragama Hindu. Perlakuan berbeda bagi peserta didik non Hindu pada saat pelajaran Agama Hindu di laksanakan. Pada kelas XII guru agama memberikan dua buah pilihan kepada peserta didik non Hindu untuk keluar kelas atau tetap di dalam kelas dengan catatan tidak mengganggu temannya yang sedang belajar agama Hindu.

"Di kelas XII ada dua siswa yang muslim, satu di kelas IPB, yang satu di kelas IPA, yang dikelas IPA setiap pelajaran saya dia otomatis keluar tanpa saya suruh, namun di kelas IPB Yogi Maulana saya suruh namun dia memilih tetap di dalam kelas, saya perbolehkan dengan catatan tidak mengganggu temannya,"tutur bu mangku panggilan akrab I Nyoman Suwartini, gru agama Hindu Kelas XII ${ }^{3}$

Hal berbeda justru terjadi di kelas X. Kegiatan belajar agama Hindu diikuti oleh seluruh siswa baik Hindu maupun non Hindu. Hal ini dikarenakan kekhawatiran guru pendidikan agama Hindu jika mengeluarkan siswa pada saat pelajaran agama Hindu berlangsung siswa tidak terkontrol keberadaannya.

"Saya khawatir, jika anak-anak non Hindu saya suruh belajar di perpustakaan mereka malah kabur sehingga tidak terkontrol keberadaan mereka" Tutur Widhiarsa guru pendidikan agama kelas X. ${ }^{4}$

Terkait dengan peserta didik muslim ketika pelajaran agama Hindu, waka Kurikulum SMA Pariwisata Saraswati mengungkapkan bahwa ia lebih condong menyetujui pada saat pelajaran Agama Hindu seluruh peserta didik tetap berada di kelas. Bagi siswa yang non Hindu dapat belajar sendiri di dalam kelas tanpa harus mengganggu temannya yang sedang mengikuti pelajaran agama Hindu.

"Lebih baik siswa tetap berada di dalam kelas dari pada kluyuran di luar tanpa ada yang mengawasi. Sebab bisa jadi

\footnotetext{
${ }^{3}$ Wawancara dengan I Nyoman Suwartini (BU Mangku) Guru Agama Hindu Kelas XII

${ }^{4}$ Wawancara dengan I wayan Widhiarsa guru pendidikan agama Hindu kelas X Maret 2015
} 
jika mereka disuruh belajar di perpustakaan meraka malah bermain-main di luar. Tutur Mertha Wiriawan Waka Kurikulum SMA Pariwisata Saraswati. ${ }^{5}$

\section{Kurikulum dan KBM Pendidikan Agama Islam}

Guru PAI pada SMA Pariwisata Saraswati merupakan guru bantu. Tugas utamanya adalah mengajar PAI pada SMA N 1 Semarapura. Selain membantu di SMA 1 Pariwisata Saraswati, Guru PAI ini juga menjadi guru bantu di SMK PGRI dan SMA Yapparindo Semarapura. Awal guru PAI mengajar pada berbagai SMA dikarenakan untuk memenuhi jadwal mengajar 24 jam seminggu sebagai syarat untuk memperoleh sertifikasi guru. Guru PAI berinisiatif untuk mencari SMA yang terdapat siswa muslim dan belum ada guru PAInya. Namun setelah Kurikulum 2013 (K13) diberlakukan di SMAN 1 Semarapura jam mengajar guru PAI di SMA 1 telah memenuhi 24 jam bahkan lebih karena jam mengajar dalam satu minggu 3 jam. ${ }^{6}$

Terpenuhinya jam mengajar pada satu sekolah tidak lantas menyebabkan guru PAI melepaskan tanggung jawab untuk mengajar pada sekolah lain. Ia tergerak untuk tetap mengajar siswa siswa dari sekolah lain karena merasa ikut bertanggung jawab atas nasib siswasiswa muslim yang sekolahnya tidak terdapat guru PAI.

Kurikulum yang berlaku pada SMA Pariwisata Saraswati adalah KTSP, namun guru pendidikan agama Islam tetap materi pembelajaran PAI Kurikulum 2013. Hal ini dikarenakan SMA Pariwisata pernah menggunakan K13 selama 1 tahun sebelum akhirnya kembali pada KTSP. Alasan lain tentang materi pembelajaran yang digunakan untuk mengajar di SMA Pariwisata Saraswati adalah untuk mempermudah guru PAI dalam menyusun materi. Sebab menurutnya apabila menggunakan dua buah kurikulum yang berbeda akan membuat guru

\footnotetext{
${ }^{5}$ Wawancara dengan I gedhe Mertha wiriawan Waka Kurikulum SMA Pariwisata Saraswati Maret 2015.

${ }^{6}$ Wawancara dengan Diinul Qayyimah, Guru PAI SMA 1 Semarapura, SMA Pariwisata saraswati, SMK PGRI Semarapura dan SMK Yaaparindo Semarapura Maret 2015
} 
kesulitan dalam memberikan pelajaran karena guru akan sibuk pada persoalan menyusun perangkat dan administrasi pembelajaran.

"Itulah kesulitan saya, di satu sisi saya harus mengajar anakanak agar memperoleh pemahaman pendidikan agamanya di satu sisi saya harus menggunakan kurikulum yang berbeda. Oleh karena itu saya memutuskan untuk menggunakan kurikulum yang sama dengan yang ada di SMAN 1 hanya saja jamnya saya kurangi. Kasihan mereka tidak mendapat pelajaran agama sesuai dengan keyakinannya,"tutur Diinul ${ }^{7}$

Kegiatan belajar mengajar (KBM) PAI tidak dilaksanakan di sekolah melainkan berkumpul di lantai 2 madrasah Diniyah, Masjid Al Fatah Kampung Jawa di Kecamatan Semarapura. Kegiatan belajar mengajar ini dilakukan bersama-sama dengan siswa muslim dari SMK swasta lain seperti SMK PGRI, dan SMK Yapparindo.

KBM PAI pada kelas X dilaksanakan setiap hari selasa pukul 15.00-17.00, sedangkan KBM kelas XI dan XII dilaksakan setiap hari Jumat mulai pukul 14.00 sampai dengan pukul 16.30 waktu setempat. Namun ketika guru berhalangan hadir pada hari yang telah disepakati bersama guru akan memindah jam pelajaran agama pada hari Sabtu atau Minggu.

Hambatan-hambatan yang dialami oleh guru PAI dalam KBM adalah kedisiplinan peserta didik untuk datang tepat pada waktunya dan keinginan peserta didik untuk memperoleh pelajaran PAI di sekolah. Hal tersebut dapat terlihat dari beberapa kali observasi yang dilakukan oleh peneliti di masjid Al Fattah.

Guru PAI sangat jarang berkunjung ke SMA Pariwisata Saraswati. Ia hanya memberikan kabar melalui telepon ke sekolah agar sekolah mengumumkan kepada siswa muslim bahwa pelajaran PAI dilaksanakan di masjid Al Fatah di Kampung Jawa. Biasanya pada jam istirahat pengumuman itu disampaikan staf tata usaha kepada peserta didik beragama Islam SMA Pariwisata Saraswati melalui pengeras suara

${ }^{7}$ Wawancara dengan Diinul Qayimah Guru PAI SMA Pariwisata saraswati 
bahwa pelajaran agama Islam akan dilaksanakan pukul 14.00 di masjid Al Fatah Kampung Jawa.

Pada saat observasi dilakukan dari pukul 14.00 sampai dengan pukul 15.30 waktu setempat hanya dua orang saja murid kelas XI yang datang ke masjid untuk belajar PAI. Dua orang ini pun datang tidak pada jam yang sama jeda waktu antara dua siswa yang datang lebih dari setengah jam.

Menurut Guru PAI, problem yang dihadapi dalam memberikan pelajaran PAI di Sekolah swasta adalah kedisiplinan siswa untuk mengikuti pelajaran PAI yang diampunya. Terkadang dalam satu semester absensi siswa tidak sesuai dengan yang diharapkan. Terkadang ia guru PAI rela menunggu sampai jam pelajaran PAI selesai namun tidak satupun siswa yang datang. Namun demikian ia selalu memberikan pengertian kepada siswanya agar senantiasa hadir pada saat pelajaran PAI yang dieselenggarakan di masjid Al Fatah.

Problem kedua adalah menyelesaikan Kompetensi dasar kepada siswa muslim yang ikut pelajaran PAI di sekolah swasta. Jika di sekolah Negeri yaitu di SMAN 1 Semarapura tempat ia bertugas, problem menyelesaikan seluruh standar kompetensi dasar dan kompetensi dasar tidak ia temukan, siswa muslim di SMA negeri jauh lebih banyak dibandingkan dengan sekolah swasta dan penyelenggaraan pembelajaran juga dilakukan di perpustakaan sekolah sehingga mudah dalam mengontrol peserta didik. Namun di sekolah swasta menurut guru PAI kelahiran Banyuwangi Jawa Timur ia harus menemukan metode pembelajaran yang tepat sehingga bisa menyelesaikan seluruh standar kompetensi dan kompetensi dasar PAI. Salah satunya adalah dengan cara menyelesaikan beberapa bab yang terdiri dari beberapa standar kompetensi dan kompetensi dasar sekaligus. Hal ini ia lakukan agar dapat menyelesaikan seluruh standar kompetensi yang telah ditetapkan oleh KTSP.

Guru PAI, sebenarnya merasa kasihan terhadap siswa-siswa muslim yang ada di sekolah swasta di Kabupaten Klungkung khususnya di kecamatan Semarapura. Ia merasa tidak tega jika harus meninggalkan 
siswa-siswa muslim tanpa mendapat pelajaran Pendidikan Agama Islam. Memang tujuan awal mengajar di SMA swasta adalah untuk memenuhi 24 jam pelajaran sebagai syarat mendapat sertifikasi. Namun ketika jam mengajar di SMA Negeri ia telah memenuhi syarat 24 jam dalam satu minggu ia merasa tetap berkewajiban untuk memberikan pelajaran PAI di sekolah swasta.

Hasil penggalian data pada salah satu peserta didik terungkap alasan mengapa ia jarang mengikuti pelajaran PAI. Diungkapkan bahwa selama hampir satu semester ia baru sekali masuk mengikuti pelajaran PAI. Hal ini dikarenakan waktu pelajaran PAI bertabrakan dengan jadwal praktik massage di sekolah, sehingga ia merasa sayang untuk meninggalkan praktik massage di sekolah. Dengan menguasai praktik massage ia berharap dapat bekerja pada salon kecantikan selepas ia sekolah di SMA.

"Saya merasa rugi pak kalau meninggalkan pelajaran praktik massage, sebab kalau sekali saja tidak mengikuti pelajaran praktik massage saya akan ketinggalan pak, kalau pelajaran agama bisa dipelajari di rumah karena ada bukunya", tutur Ayu siswa kelas XI

Persoalan-persoalan pada kegiatan belajar mengajar Pendidikan Agama Islam pada obyek penelitian sebagaimana disebutkan di atas hampir sama dengan persoalan-persoalan yang dihadapi oleh sekolah swasta lainnya di Kecamatan Semarapura, Kabupaten Klungkung. Hampir seluruh peserta didik muslim di sekolah swasta jarang mengikuti pelajaran pendidikan agama yang diselenggarakan di luar sekolah seperti halnya di Masjid Al Fatah, Kampung Jawa. Meskipun diselenggarakan di luar jam sekolah namun tetap saja jumlah peserta didik yang hadir dalam pertemuan pembelajaran dari beberapa kali observasi dilakukan tidak seperti yang diharapkan guru, yaitu 50 persen siswanya hadir.

\section{PEMBAHASAN}

Sebelum masuk pada pembahasan mengenai pendidikan agama berwawasan multikultural terlebih dahulu akan dipaparkan hal-hal yang 
berhubungan dengan kebijakan sekolah dalam pendidikan multiukultural. Hal-hal yang berhubungan dengan pendidikan multikultural berupa budaya sekolah serta sarana dan prasarana yang ada di lingkungan SMA subyek penelitian.

Budaya sekolah yang dimaksud meliputi visi misi sekolah, simbolsimbol multikultural, kesempatan beribadah, dan doa bersama yang dilaksanakan oleh sekolah. Sarana dan prasarana yang dimaksud berupa sarana peribadatan dan kantin sekolah. Sebagai penegasan kembali bahwa di SMA Pariwisata Saraswati agama yang hidup dan dipeluk warga sekolah hanya ada dua yaitu mayoritas Hindu dan minoritas Islam. Dari 961 siswa hanya 13 orang yang memeluk agama Islam.

Pelajaran agama menjadi salah satu pelajaran agama terpenting dalam menumbuhkan keimanan, kepedulian, dan menumbuhkan karakter keagamaan yang toleran, peduli sesama, cinta kasih. Oleh karena itu pendidikan agama wajib diberikan kepada seluruh peserta didik di sekolah. Salah satu kuesioner yang diberikan kepada peserta didik adalah kesukaan terhadap mata pelajaran agama di sekolah. Dari 33 peserta didik yang dijadikan subyek penelitian 23 diantaranya adalah peserta didik beragama Hindu. Sisanya, yaitu 10 orang adalah peserta didik beragama Islam. Kuesioner yang dijawab peserta didik menghasilkan pernyataan tingkat kesukaan mata pelajaran agama oleh peserta didik sebagaimana dilihat pada tabel berikut.

Tabel 2 Tingkat Kesukaan Peserta Didik Terhadap Mata Pelajaran

\begin{tabular}{|l|l|c|c|c|c|}
\hline & & Frequency & Percent & Valid Percent & $\begin{array}{c}\text { Cumulative } \\
\text { Percent }\end{array}$ \\
\hline Valid & sangat suka & 17 & 51.5 & 51.5 & 51.5 \\
\cline { 2 - 6 } & suka & 14 & 42.4 & 42.4 & 93.9 \\
\cline { 2 - 6 } & biasa saja & 2 & 6.1 & 6.1 & 100.0 \\
\cline { 2 - 6 } & Total & 33 & 100.0 & 100.0 & \\
\hline
\end{tabular}

Dari tabel tersebut terlihat bahwa, dari 33 peserta didik yang menjawab sangat suka dan suka sebanyak 31 orang dan 2 orang menganggap mata pelajaran pendidikan agama adalah mata pelajaran 
yang biasa saja. Dengan demikian dapat disimpulkan bahwa mata pelajaran agama di sekolah ini termasuk mata pelajaran yang disukai oleh peserta didik.

Namun demikian meskipun merupakan pelajaran yang disukai oleh peserta didik, pelajaran agama masih belum bisa mengalahkan tingkat kesukaan peserta didik terhadap pelajaran lain. Dari pertanyaan terbuka diperoleh data bahwa dari 33 sampel hanya 9 orang yang menyatakan bahwa pelajaran agama termasuk 5 pelajaran favorit di sekolah. mata pelajaran agama masih kalah favorit dibandingkan dengan mata pelajaran bahasa Inggris, bahasa Indonesia, sosiologi, Biologi, sejarah, bahasa Jepang dan lainnya.

\section{Visi-Misi Sekolah}

Dilihat dari visi sekolah SMA Pariwisata Saraswati secara umum telah berusaha memasukan mempersatukan nilai-nilai multikultural dalam cita-cita yang diembannya. Visi tersebut adalah menjadikan SMA Pariwisata Saraswati sebagai lembaga pendidikan yang favorit dan dicintai oleh masyarakat, unggul dalam mutu, sehingga mampu menghasilkan tamatan yang kredibel, berahlak, berpengetahuan dan berketrampilan yang berlandaskan budaya bangsa. Kata-kata berahlak dan berlandaskan budaya bangsa menunjukkan sebuah cita-cita yang luhur mempersatukan warga sekolah meskipun berasal dari etnis, gender, agama dan status sosial yang berbeda.

Visi sekolah memang secara ideal harus mengandung nilai multikulturalisme, yaitu suatu paham yang memandang perbedaan yang ada dalam masyarakat baik etnis, agama, dan bahasa adalah sebuah kenyataan. Perbedaan tersebut bukanlah sebuah perpecahan namun justru mempersatukan. Modood dalam Hefner (2001:36) mengungkapkan bahwa paham multikultural menjembatani kaum marjinal untuk tetap eksis dalam kehidupan bermasyarakat. Jika merujuk pada pendapat Hefner kunci dari visi yang bersifat multikultural adalah penghormatan atas hak-hak warga sekolah untuk berekspresi yang tidak berbenturan dengan aturan-aturan dasar dari lembaga sekolah tersebut. 
Visi sekolah tersebut kemudian dibungkus pada misi sekolah sebagai langkah untuk mencapai cita-cita sekolah yaitu melaksanakan kegiatan pembelajaran dan bimbingan secara terjadwal dan efektif sehingga setiap siswa dapat berkembang secara, optimal, sesuai potensi yang dimiliki, mensosialisasikan dan menumbuhkan semangat keunggulan dan kompetitif secara intensif kepada seluruh warga sekolah, serta membina siswa melalui jalur-jalur pembinaan kesiswaan untuk menghasilkan pribadi-pribadi yang bertaqwa terhadap Tuhan Yang Maha Esa, berbudi pekerti luhur, menguasai ilmu dan keterampilan serta cinta tanah air dan bangsanya.

Visi dan misi sekolah sebagaimana disebutkan di atas idealnya juga diimbangi oleh simbol-simbol atau slogan yang mendukung multikulturalisme. Namun sayang, dari observasi yang dilakukan oleh peneliti tidak satupun ditemukan symbol-simbol atau slogan-slogan yang mengarah pada pendidikan multikultural. Simbol, slogan yang ada di sekolah hanya mengarah pada satu fokus saja yaitu tentang pencegahan penyalahgunaan narkoba dan HIV AIDS. Hal ini diakui oleh kepala sekolah dengan alasan bahwa pada tahun 2014 sekolah focus mengikuti perlombaan kelompok siswa peduli AIDS dan Narkoba (KSPAN) sehingga kurang memperhatikan tentang multikultural.

\section{Doa Bersama}

Budaya sekolah yang lain adalah doa bersama. Doa bersama yang diberlakukan pada SMA Pariwisata Saraswati dilakukan dengan cara Hindu sebagai agama yang mayoritas dipeluk oleh warga sekolah. Seluruh warga sekolah baik Hindu maupun non Hindu berkumpul setiap pagi antara jam 07.15 sampai dengan pukul 07.30 waktu setempat di lapangan upacara sekolah. Bagi warga sekolah pemeluk agama Hindu doa bersama dilakukan dengan cara Puja Trisandya mulai dari sikap tangan pranayama, amustikarana, hingga pengucapan mantra trisandaya. Bagi pemeluk agama minoritas dipersilahkan untuk berdoa sesuai dengan agama dan kepercayaan masing masing. 
Perserta didik minoritas tidak diberi kesempatan untuk melakukan doa dengan sesama pemeluk agama dikarenakan tidak ada guru yang mengawasi dan mengontrol secara langsung doa yang dilakukan pemeluk agama minoritas. Dikhawatirkan jika siswa minoritas tidak dikumpulkan di lapangan maka siswa tidak berdoa bersama malah kluyuran. ${ }^{8}$

\section{Fasilitas Buku Penunjang Pendidikan Agama}

Fasilitas buku penunjang pendidikan agama yang ada di perpustakaan sekolah terdiri dari buku penunjang pendidikan agama Hindu dan buku penunjang pendidikan agama Islam. Buku-buku penunjang tersebut adalah berupa kitab suci AlQuraan dan terjemahannya, kitab Bagawatgita, dan kitab Weda. Tidak ada buku-buku penunjang pendidikan agama selain kitab-kitab yang disebutkan.

Terkait dengan buku-buku bantuan berupa buku agama pegangan siswa bantuan dari pemerintah Kemenag, perpustakaan tidak memiliki lagi. Tidak adanya buku-buku pengangan mata pelajaran agama tersebut dikarenakan buku tersebut dipinjam oleh siswa dan tidak pernah dikembalikan lagi.

Terkait dengan ketuntasan pelajaran pendidikan agama untuk guru agama Hindu dipergunakan LKS yang bekerja sama dengan penerbit di luar pemerintah. Sedangkan untuk siswa beragama Islam, guru agama biasanya meminjamkan buku pelajaran agama kepada siswa untuk di fotokopi sebagai bahan belajar di rumah.

\section{Budaya Kantin Sekolah}

Kantin sekolah yang terdapat di SMA Pariwisata Saraswati mencerminkan sekolah mengakomodir siswa-siswa yang non Hindu. Dari 8 kantin yang ada, satu diantaranya disewa oleh pedagang muslim yang menempati lapak kantin melalui proses lelang. Semua kantin yang ada di SMA Pariwisata Saraswati tidak terdapat makanan yang diharamkan oleh salah satu agama, seperti contohnya daging babi.

${ }^{8}$ Hasil wawancara dengan Kepala dan waka kurikulum SMA Pariwisata Saraswati Maret 2015 
Seluruh siswa minoritas ketika jam istirahat dimulai selalu makan dan minum pada kantin Bakso yang dikelola oleh pedagang muslim. Hal tersebut tidak berlaku sebaliknya siswa beragama mayoritaspun juga menikmati bakso pada kantin pedang muslim.

\section{Budaya Pergaulan Sehari-hari Siswa}

Budaya pergaulan sehari diantara peserta didik cenderung bersifat inklusif dalam satu kelas dan tidak pernah terlihat tanda-tanda ekslusifisme. Bersifat inklusif maksudnya adalah peserta didik dalam satu kelas tidak pernah mempermasalahkan akan agama yang dianut. Peserta didik minoritas tidak merasakan dibedakan di antara kawankawannya yang mayoritas baik dilihat dari agama maupun asal suku mereka.

Inklusifitas peserta didik hanya terjadi pada anggota kelas saja, ketika peserta didik berada di luar kelas mereka cenderung lebih dekat kepada teman-teman satu kelas (ekslusif). Bahkan untuk peserta didik penganut agama minoritas di sekolah ini antara tingkatan kelas atas maupun kelas bawah tidak sedekat hubungan siswa-siswa dalam satu kelas. Mereka hanya bertemu ketika dikumpulkan pada pertemuan pelajaran agama pendidikan agama Islam.

Untuk urusan asmara antara peserta didik penganut agama minoritaspun banyak yang memiliki pacar dari siswa yang berbeda agama. Guru agama minoritas telah memberikan nasihat agar tidak berpacaran pada usia sekolah namun siswa menganggap pacaran hanyalah sebuah penyemangat untuk belajar.

"Pacar saya beragama Hindu pak, tapi pacarannya hanya di sekolah saja di rumah saya jarang keluar, saya pinginnya sih punya pacar yang muslim tapi gimana ya tidak ada stok sih pak," tutur seorang siswa berlogat jawa timuran yang disambut riuh tawa kawan-kawannya. ${ }^{9}$

${ }^{9}$ Wawancara dengan salah seorang siswa pada pertemuan di ruang Praktik restaurant Sekolah Maret 2015. Sebenarnya wawancara ini dilakukan dengan beberapa siswa secara bersamaan, dan rata-rata peserta didik yang pernah atau sedang memiliki pacar adalah dari agama yang berbeda 


\section{Pandangan Tenaga Pendidik dan Kependidikan tentang Multikultural}

Sebagaimana telah disebutkan di atas bahwa seluruh kependidikan pada obyek penelitian beragama Hindu. Sedangkan tenaga pendidik dari dari 59 orang hanya 2 yang beragama Islam. Dua orang guru tersebut adalah Guru Fisika yang diperbantukan oleh sekolah dan diberi honor oleh sekolah serta guru agama Islam yang tidak diberi honor oleh sekolah. Dari segi pelayanan kepada peserta didik meskipun seluruh tenaga pendidik beragama Hindu tidak pernah membeda-bedakan peserta didiknya. Seluruh peserta didik diperlakukan secara sama baik laki-laki, perempuan, agama maupun suku mereka. Tenaga pendidik tidak pernah mengenal tentang konsep-konsep multikultural namun pada dataran praktik sehari-hari di sekolah dalam hal pelayanan telah mempraktikan beberapa dimensi-dimensi multikultural sebagaimana teori pendidikan multikultural yang diutarakan oleh Banks yaitu equity paedagoy dan an empowering school culture and sosial culture (Banks, 2010:22)

Data yang diperoleh dari tenaga pendidik terkait wawasan multikultural menunjukkan secara umum guru agama pada SMA obyek penelitian hanya memahami multikultural sebatas pada perbedaan suku saja. Tiga orang guru agama baik guru pendidikan agama Hindu maupun Islam berpendapat bahwa multikultural terbatas pada perbedaan etnis semata. Mereka tidak mengetahui bahwa wawasan pendidikan multikultural tersebut meliputi perbedaan jenis kelamin, status sosial, agama, dan etnis yang kesemuanya itu tidak harus menimbulkan perpecahan namun justru mempersatukan warga sekolah dengan tidak menafikan perbedaan-perbedaan dari masing-masing kelompok baik agama, etnis, jenis kelamin maupun status sosial.

Dari tiga orang guru agama yang mengajar di SMA Pariwisata Saraswati, tidak satupun yang pernah mendapat pengetahuan tentang wawasan multikultural. Pengetahuan guru agama terkait dengan multikultural baru sebatas pada pemaknaan teks kata multi kultur. Kata multi dimaknai oleh guru agama sebagai banyak variasi dan kultur 
dimaknai sebagai budaya. Dari dua pemaknaan kata multi kultural tersebut, guru-guru agama memaknainya sebagai keanekaragaman budaya yang ada disekitar kita. Hal-hal yang terkait dengan keanekaragaman agama, jenis kelamin serta status sosial oleh guruguru agama dianggap bukan bagian dari multikultural.

Data yang diperoleh dari guru-guru agama mengungkapkan bahwa selama ini guru agama di SMA ini belum pernah memperoleh sosialisasi terkait pendidikan multikultural baik yang diselenggarakan oleh pemerintah ataupun yang diselenggarakan oleh lembaga swasta. Oleh karena itu pola mengajar guru-guru agama hanya bergantung pada materi-materi yang ada dalam buku mata pelajaran agama. Secara administrasi, guru-guru agama di SMA Pariwisata Saraswati telah menyusun kurikulum, silabus sampai dengan rencana pelaksanaan pembelajaran. Namun secara praktik guru agama masih terpaku pada buku mata pelajaran agama.

Terkait dengan pengetahuan multikultural peserta didik, data yang diperoleh dari tiga guru agama pada subyek penelitian terungkap bahwa mereka yakin peserta didik yang mereka ajar telah memperoleh pengetahuan terkait dengan multikultural baik melalui pelajaran agama ataupun pelajaran yang lain seperti Pendidikan Kewarganegaraan (PKn). Pada mata pelajaran agama materi-materi tentang multikultural ada yang secara khusus membahas multikultural, namun ada juga yang disisipkan pada materi-materi lain.

Seperti pada materi pelajaran pendidikan agama Islam kelas XI, materi multikultural disusun khusus bab tersendiri yaitu tentang toleransi sebagai alat pemersatu bangsa. Pada materi tersebut peserta didik diajak untuk menganalisis perilaku toleransi dan menghindarkan diri dari tindak kekerasan. Tujuan akhir dari materi tersebut adalah pembiasaan peserta didik pada perilaku toleran dan menjauhi tindak kekerasan. Pada materi tersebut peserta didik diminta untuk membuka relung hati tentang pentingnya menjaga persatuan dan kesatuan bangsa. Menjaga persatuan dan kesatuan bangsa tersebut, dapat dilakukan 
dengan berbagai macam cara yaitu menghormati orang lain, menjaga lisan agar tidak menyakiti orang lain, serta menghargai perbedaan yang di sekitar kita. Perbedaan tersebut dapat berupa perbedaan suku, jenis kelamin, agama, usia, antar kelompok masyarakat dan lain sebagainya. Materi ini pada bab toleransi juga mengajarkan tentang perilaku-perilaku yang harus dibina dan sesuai dengan ajaran Islam. Ajaran tersebut seperti saling menghargai adanya perbedaan keyakinan, saling menghargai adanya perbedaan pendapat, belajar ber-empati, saling menghargai dan saling menghormati (Buku Pelajaran PAI Kelas XI).

Hal berbeda ditemui pada mata pelajaran agama Hindu. Pada mata pelajaran agama Hindu di SMA Pariwisata Saraswati, materimateri terkait dengan pendidikan multikultural tidak dibahas secara khusus dalam bab-bab tertentu. Bahkan dalam dokumen administrasi yang meliputi penyusunan Kurikulum, silabus, dan RPP dan bahan buku pelajaran pendidikan agama Hindu kelas X, XI, dan XII materi yang terkait dengan multikultural tidak ada. Hal tersebut diakui oleh I Nyoman Suwartini guru pendidikan agama Hindu kelas XII. Bu Mangku panggilan akrab Nyoman Suwartini dengan jelas mengungkapkan bahwa di kelas XII materi terkait multikultural tidak ada, begitu juga pada kelas X dan XII. Ia mengetahuinya karena sampai akhir tahun 2014, ia menjabat waka Kurikulum. Kurikulum pendidikan dan mengajar mata pelajaran pendidikan agama Hindu, maka dari itu ia setidaknya sedikit banyak tahu tentang mata pelajaran Agama Hindu.

Materi multikultural pada pelajaran pendidikan agama Hindu menurut Bu Mangku biasanya disisipkan pada materi materi seperti catur warna catur asrama, dan catur purusa Artha. Meskipun catur warna, asrama, dan purusa artha adalah mengatur pembagian atau penggolongan masyarakat dan bagaimana mengatur pergaulan di antara wangsa (kasta/warna) pada sesama pemeluk agama. Tema-tema tersebut kemudian disisipi oleh bagaimana bergaul diantara teman dan lain agama agar tidak menimbulkan permusuhan dan perpecahan. 


\section{Kesempatan Menjalankan Ibadah}

Pembelajaran di SMA Pariwisata Saraswati dilaksanakan pada hari Senin sampai Sabtu mulai pukul 07.15 sampai dengan pukul 14.00 waktu setempat. Diawali dengan doa bersama dan diakhiri pada jam 14.00. Jam pembelajaran yang seperti ini tentunya berpengaruh pada kesempatan beribadah baik peserta didik beragama Hindu maupun peserta didik beragama Islam. Terkait pemberian kesempatan beribadah pada seluruh warga sekolahnya, pihak Yayasan dalam hal ini diwakili oleh Kepala Sekolah menetapkan kebijakan pemberian kesempatan beribadah kepada seluruh warga sekolah selama satu jam pelajaran (setara 45 menit). Kesempatan tersebut diberikan dalam rangka memenuhi hak-hak beribadah kepada warga sekolah atas agama yang dipeluknya.

Pada pemeluk agama Hindu di SMA ini setiap 1 bulan 2 kali mengadakan upacara keagamaan Purnama dan Tilem. Purnama dan Tilem adalah adalah hari suci bagi umat Hindu, dirayakan untuk memohon berkah dan karunia dari Hyang Widhi. Purnama, sesuai dengan namanya, jatuh setiap malam bulan penuh (Sukla Paksa). Tilem dirayakan setiap malam pada waktu bulan mati (Krisna Paksa). Kedua hari suci ini dirayakan setiap 30 atau 29 hari sekali. Pada Purnama dilakukan pemujaan terhadap Sang Hyang Chandra, sedangkan pada Tilem dilakukan pemujaan terhadap Sang Hyang Surya. Keduanya merupakan manifestasi dari Hyang Widhi yang berfungsi sebagai pelebur segala kotoran (mala). Pada kedua hari ini hendaknya diadakan upacara persembahyangan dengan rangkaiannya berupa upakara yadnya.

Sekolah memberikan kesempatan kepada peserta didik beragama Hindu selama satu jam pelajaran. Karena jumlah peserta didik penganut Hindu sangat banyak maka dalam satu jam pelajaran tersebut dibagi menjadi dua shift. Kegiatan persembahyangan Purnama dan Tilem dilakukan pada pukul 07.30 Setelah doa bersama Tri Sandya. Pada upacara ini, seluruh warga sekolah penganut Hindu menggunakan 
pakaian adat berupa udeng (ikat kepala) dan kain, sedangkan perempuan menggunakan kebaya khas Bali.

Perlakukan sedikit berbeda diberikan kepada peserta didik minoritas pada saat melaksanakan kegiatan ibadah salat Jumat setiap hari Jumat. Meskipun sekolah memberikan kesempatan untuk melaksanakan kewajiban beribadah sesuai dengan agama dan kepercayaannya selama satu jam pelajaran, namun kebijakan menempatkan mata pelajaran penting pada jam-jam pelaksanaan salat Jumat tersebut dianggap siswa tidak mendukung kegiatan ibadah. Seperti contoh pada saat jam ibadah salat jumat yang bertepatan pada jam 6-7 (11.45-13.15 adalah mata pelajaran Matematika atau Fisika, Biologi, Bahasa Inggris Pariwisata, kimia yang tentu saja siswa diberi pilihan kehilangan materi pelajaran selama 1 jam pelajaran ataukah melaksanakan kewajiban sebagai pemeluk muslim yang taat beragama. Beberapa peserta didik laki memilih melaksanakan salat jumat, namun beberapa yang lain memilih tetap mengikuti pelajaran dengan dalih jangan sampai 3 kali berturut turt tidak melaksanakan salat Jumat

Kecuali untuk mata pelajaran Fisika yang diampu oleh Prihandaka seorang muslim. Prihandaka diperbantukan dari SMP 2 Sidemen untuk mengajar Fisika di SMA Pariwisata Saraswati ini memberikan kesempatan siswa pada ssat jam pelajarannya untuk beribadah salat jumat pada masjid terdekat. Hal ini dikarenakan iapun juga melaksanakan salat jumat. Namun demikian jam pembelajaran mata pelajaran Fisika tetap berkurang berkurang satu jam pelajaran.

Ada lontaran perkataan dari salah seorang guru terkait dengan praktik ibadah salat Jumat bagi warga muslim. Mungkin karena kurangnya pemahaman tentang ajaran agama islam ia melontarkan perkataan mengapa salat Jumat tidak dilaksanakan di hari lain saja seperti hari Minggu sehingga tidak mengganggu jam pelajaran sekolah.

Persoalan-persoalan memandang ajaran agama orang lain dengan menggunakan kacamatan ajaran agama sendiri dari hasil penggalian data di lapangan masih sering terjadi. Hal ini dapat terjadi karena kurang terbukanya antar pemeluk agama yang berlainan untuk saling 
berkomunikasi dan berdialog. Dengan melakukan komunikasi dan berdialog sebenarnya persoalan-persoalan yang terkait dengan ritual keagamaan orang lain dapat menimbulkan saling pengertian. Dialog antar agama bukan berarti saling menjatuhkan atau saling mematahkan argumen ajaran orang lain, tetapi lebih pada memberikan pemahaman ajaran agama dari masing-masing pemeluk.

\section{Presepsi Peserta didik Tentang Multikultural}

Hasil penggalian data kepada peserta didik kelas X, XI, dan XII baik yang beragama Hindu maupun Islam terungkap bahwa sebagian besar pengetahuan mereka terkait dengan hal-hal yang berhubungan dengan multikultural diperoleh melalui pelajaran lain seperti Pendidikan Kewarganegaraan. Pada mata pelajaran agama hanya peserta didik beragama islam saja yang mengungkapkan bahwa materi multikultural diperoleh juga pada mata pelajaran pendidikan agama Islam. sedangkan pada peserta didik beragama Hindu dari hasil penggalian data terungkap bahwa hal-hal yang terkait dengan multikultural tidak ada. Sebagian besar peserta didik beragama Hindu mengungkapkan bahwa pelajaran agama Hindu di sekolah lebih banyak pada persoalan Yajnya, Upakara, dan ritual keagamaan.

Peserta didik memahami tentang multikultural baru terbatas pada perbedaan suku, dan bahasa saja, namun jika dikaitkan pada mata pelajaran PKn pada kelas X mereka baru menyadari bahwa multikultural tidak terbatas pada suku saja melainkan juga pada perbedaan agama. Pada tataran praktik sehari-hari di sekolah sebagian besar peserta didik telah mempraktikan tingkah laku yang berwawasan multikultural. Peserta didik dalam bergaul tidak lagi memperhatikan asal muasal peserta didik apakah dari Suku Jawa, Lombok Bali, atau dari Madura. Peserta didik dalam pergaulan sehari-hari bergaul layaknya tidak ada perbedaan diantara mereka meskipun pada batas-batas tertentu mereka saling menghormati perbedaan keyakinan mereka. Seperti dicontohkan ketika berkunjung di rumah teman, mereka akan menghormati temantemannya dengan tidak menyuguhkan makanan atau minuman yang dilarang oleh masing-masing agama seperti tidak menyuguhkan daging 
babi dan lawar ${ }^{10}$ kepada peserta didik muslim, sebaliknya tidak memberikan menyuguhkan daging sapi kepada peserta didik Hindu.

Begitu juga saling memberikan ucapan selamat hari raya keagamaan atas teman-teman peserta didik yang sedang merayakan. Mengucapkan selamat hari raya Idul Fitri bagi peserta didik muslim dan selamat hari raya Nyepi bagi peserta didik Hindu baik secara langsung ataupun melalui Short message service (SMS) telepon genggam.

Peserta didik tidak berkeberatan jika harus bertetangga dengan orang-orang yang berbeda dengan dirinya baik dari etnis maupun agama yang berbeda. Pernyataan tersebut terungkap dari jawaban atas kuesioner yang diberikan peserta didik terhadap kesediaan bertetangga dengan orang yang berbeda baik suku maupun keyakinan. Sebanyak $66,7 \%$ menjawab bersedia, 24, $2 \%$ menjawab sangat besedia, dan 9,1 $\%$ merasa kurang bersedia jika harus bertetangga dengan orang yang berbeda suku maupun keyakinan. Dengan demikian dapat disimpulkan bahwa sebagian besar peserta didik sangat terbuka kepada siapa saja terhadap orang yang ingin tinggal di sekitar lingkungan mereka.

Terkait dengan fanatisme dalam beragama peserta didik dimintai sikapnya terkait dengan agama yang dipeluk adalah agama yang paling benar dan orang lain harus masuk agama kita. Hasilnya 100 persen menjawab tidak sepakat dengan pernyataan ini. Dalam menjalankan ibadahnya peserta didik menyatakan harus fanatik dalam beragama, namun demikian tidak boleh memaksa orang lain untuk masuk memeluk agama yang dianutnya. Hal ini bertentangan dengan toleransi antar umat beragama.

Fanatisme yang tidak berlebihan dalam beragama dengan cara menghormati kehidupan agama orang lain juga tercermin dalam pernyataan peserta didik terkait dengan dihormatinya pemeluk agama lain dalam mengadakan kegiatan keagamaan meski berbeda dengan keyakinan peserta didik. Sebanyak 51, 5\% peserta didik menyatakan

${ }^{10}$ Lawar adalah sejenis sayur-sayuran yang direbus kemudian diberi bumbu kelapa parut dan darah ayam atau babi. Di jawa sayuran lawar ini sejenis sayur urap/gudangan hanya tidak ditambah dengan darah ayam atau babi. 
tidak setuju, 18,2 sangat tidak setuju dan kurang jika kegiatan agama yang berbeda dengan keyakinan beragama peserta didik di tentang atau dilarang. Sisanya $12,1 \%$ menjawab setuju tentang pelarangan kegiatan keagamaan yang dilakukan umat minoritas dilingkungan mereka.

Terkait dengan tolong menolong kepada sesama manusia yang berbeda suku dan keyakinan agama yang berbeda sebanyak 97\% peserta didik menyatakan sangat bersedia dan bersedia membantu sesama manusia tanpa memandang suku dan keyakinan agama yang ditolong. Hal ini menunjukan bahwa dalam hal memberikan bantuan kepada orang lain persoalan suku dan keyakinan beragama yang berbeda tidak menjadi prioritas mereka. Keinginan peserta didik membantu orang lain yang membutuhkan tidak didasari pada sentimen etnis maupun agama.

Temuan penelitian di atas jika dianalisis secara holistik dapat terlihat bahwa pendidikan agama berbasis multikultural menjadi sesuatu yang penting di tengah dominasi budaya pada masyarakat tertentu. Dominasi budaya terhadap budaya yang lebih lemah dapat dengan mudah memicu konflik, bahkan agregasi atau perlawanan. Pendidikan agama berbasis multikultural idealnya mampu memberikan angin sejuk dalam menumbuhkan kesadaran di tengah pulralisme agama dan budaya.

\section{ANALISIS}

Dari pemaparan data sebagaimana tersebut di atas terungkap bahwa meskipun kecil namun masih ada semangat monokultur baik oleh sekolah maupun dalam implementasi pendidikan agama di sekolah yang mewarnai kebijakan pendidikan di sekolah. Labeling dan justifikasi negative dari pemeluk agama ataupun pada etnis mayoritas terhadap agama dan budaya minoritas dalam satu sekolah telah melahirkan manajemen, kurikulum, desain pembelajaran, dan model evaluasi dan berbagai pengembangan sarana dan prasarana dilakukan atas dasar prinsip monokultur. Proses pendidikan monokultur dalam lembaga 
pendidikan akan membuat seluruh pengelolaan input, proses dan output pendidikan lebih mengacu kepada nilai-nilai dominan di sekitar sekolah itu sendiri Maliki (2010: 252). Nilai-nilai, agama, budaya, jenis kelamin, serta status sosial yang lemah ditempatkan di tepi batas atau pinggiran dari atau agama yang minoritas. Pendidikan monokultur ini akan melahirkan phobia terhadap minoritas yang pada akhirnya terjadi peminggiran atau periphealisasi nilai-nilai di luar tradisi budaya atau agama yang dominan.

Dikhawatirkan, hal tersebut berlangsung secara terus menerus akan menyebabkan terjadinya proses peminggiran agama dan budaya minoritas. Pendidikan monokultur juga akan menumbuhkan sensitifitas terhadap perbedaan. Kesadaran akan perkembangan masyarakat yang kian mengarah kepada keanekaragaman budaya, latar belakang agama, latar belakang sosial, pilihan politik, status ekonomi, bahasa maupun etnisitas perlu dibangun sejak dini. Belum banyak yang menyadari bahwa kehidupan semakin majemuk, batas-batas wilayah menjadi kabur karena kemajemukan dan kemajuan teknologi. Paradigma pendidikan belum juga belum berubah masih menegembangkan prinsip monokultur yang berakibat pada pelayanan, pengelolaan pendidikan untuk mayoritas. Pandangan-pandangan tersebut sudah saatnya diubah karena dapat melahirkan berbagai masalah.

Jika ditelisk lebih jauh bahwa, pendidikan agama berbasis multikultur mengajak melihat perbedaan agama, budaya, etnis, status sosial sebagai sesuatu yang wajar. Pendidikan agama berbasis multikultural diharapkan akan melahirkan manusia-manusia yang siap bergaul, berinteraksi, bekerjasama, saling isi mengisi, saling harga menghargai, hormat menghormati sesama manusia tanpa harus saling menyakiti atau menganggap salah ajaran agama dan budaya orang lain. Dalam penyelenggaraan pendidikan agama berbasis multicultural, kepemimpinan kurikulum sekolah menjadi pemegang kunci peranan. Keberhasilan pendidikan multikultural tergantung bagaimana kurikulum sekolah itu dikemas. Pengemasan kurikulum sekolah tentunya juga akan berpengaruh pada kemasan kurikulum pendidikan agama berbasis 
multikultural. Kurikulum sekolah harus dikemas sedemikian rupa, sehingga pandangan atau prespektif pluralism, demokarasi, penghargaan atas perbedaan, dapat diterjemahkan sebagai nilai, pandangan dunia, sikap secara teoritik maupun praktik. Jadi, kurikulum pendidikan multikultural nilai budaya dan tradisi dominan tidak bisa lagi menguasai praktik pembelajaran di sekolah.

Merujuk pada konsep teori, pendidikan agama berwawasan multikultural idealnya mengusung pendekatan dialogis untuk menanamkan kesadaran hidup bersama dalam keragaman dan perbedaan (Baidhawy, 2005:75-76). Pendidikan multikultural selama ini salah dipahami hanya sebatas memasukkan isu-isu etnik atau rasial padahal lebih dari itu pendidikan multikultural juga mengedepankan isu-isu lainnya seperti relasi gender, keragaman sosial, ekonomi dan perbedaan agama serta lain sebagainya (Baidhawy:75-76). Kurikulum pendidikan agama berbasis multikultural idealnya memiliki pedomanpedoman dalam perencanaan kurikulum dan implementasinya. Pedoman tersebut meliputi dimensi isi, dimensi konstruksi pengetahuan, pengurangan prasangka, kesetaraan dalam pendidikan, serta pemberdayaan budaya sekolah dan struktur sosial yang multikultur (Banks 2002:14). Penyusunan kurikulum sekolah dan kurikulum pembelajaran pada suatu lembaga pendidikan hendaknya juga memperhatikan pluralitas dan multikulturalitas yang hidup di sekolah. Kurikulum sekolah dan kurikulum pendidikan agama harus disusun dengan prinsip-prinsip belajar hidup dalam perbedaan, pengembangan sikap toleran, empati dan simpati, membangun saling percaya, memelihara saling pengertian, menjunjung sikap saling menghargai, terbuka dalam berfikir, apresiasi dan interdepensi, resolusi konflik dan rekonsiliasi Nirkekerasan.

Konflik antar agama adalah kenyataan yang tidak terbantahkan dari masa lalu dan masa kini. Namun, konflik ini harus dikurangi sedemikian rupa karena dengan satu alasan konflik berarti mengangkangi nilai-nilai agama tentang persaudaraan dan persatuan umat manusia. Pendidikan agama harus hadir untuk menyuntikan spirit 
dan kekuatan spiritual sebagai sarana integrasi dan kohesi sosial. Pendidikan agama perlu memfungsikan agama sebagai satu cara dalam resolusi konflik.

\section{PENUTUP}

Sebagai penutup, penelitian menghasilkan 4 buah kesimpulan sebagai berikut. Pertama, beberapa budaya sekolah turut mendukung implementasi pendidikan agama berwawasan multikultural seperti kantin sekolah, kesempatan melaksanakan ibadah, dan perpustakaan. Kedua, masih ada sebagian guru guru agama pada subyek penelitian di kabupaten Klungkung memandang pendidikan multikultural terbatas pada persoalan perbedaan suku atau etnis saja belum sampai pada persoalan multikultural secara holistic sehingga kurikulum yang dibangun belum didesain memasukan nilai-nilai multikultural selain terkait dengan etnisitas, seperti perbedaan agama, jenis kelamin dan status sosial. Ketiga, persepsi siswa SMA terhadap hasil pembelajaran pendidikan agama berwawasan multikultural secara kognitif masih terbatas pada pengetahuan terkait perbedaan etnis saja, namun secara afeksi dan psikomotorik peserta didik telah mempraktikan multikultural dalam kegiatan sehari-hari di sekolah dan lingkungan. Keempat, faktor pendukung implementasi pendidikan agama berwawasan multikultural pada subyek penelitian berupa beberapa kebijakan kepala sekolah serta budaya sekolah. Faktor penghambat implementasi pendidikan gama berwawasan multicultural meliputi sumber daya guru agama yang belum memahami perosalan-persoalan terkait multikultural, tidak adanya slogan/symbol-simbol tentang multikultural di sekolah, belum disusunnya kurikulum pendidikan agama berwawasan multukultural, dan buku ajar pendidikan agama.

\section{DAFTAR PUSTAKA}

Azra, Azyumardi, 2007. "Identitas dan Krisis Budaya, Membangun Multikulturalisme Indonesia",http://www.kongresbud.budpar. go. id/58\%20ayyumardi\%20azra.htm. 
Baidhawy, Zakiyudin, 2005. Pendidikan agama berwawasan multikultural, Erlangga, Jakarta.

Banks, James A. 2002. An introduction to Multikultural Education, Allyn and Bacon Press, Boston-London.

Bogdan, Robert C, Biklen, Knopp Sofi. 1982. Qualitation Research For Education An Introduction To Theory And Methods. Allya and Bacon. Boston House.

Geriya, I Wayan, 2004, Visi dan Strategi Kebudayaan Bali ke Depan dan Penjabaran ke Dalam Misi dan Tujuan PKB. (dalam MUDRA: Jurnal Seni Budaya Vol.14 No. 1 Januari 2004). ISI Denpasar.

Hefner, Robert W, 2001, The Politics of Multikulturalism Pluralism and Citizenship in Malaysia, Singapore, and Indonesia, University of Hawaici Press, Honolulu.

Horton, Paul B. \& Hunt, Chester. L. (1984). Sosiologi, Jilid II edisi keenam. Jakarta: Erlangga.

Lubis, Akhyar Yusuf, 2006. Deskontruksi Epistemologi Modern. Jakarta: Pustaka Indonesia Satu.

Maliki, Zainudin. 2010, Sosiologi Pendidikan, Yogyakarta, Gajahmada University Press.

Nasikun. (1984). Sistem Sosial Indonesia. Jakarta: Rajawali Press.

Schlesinger, A., Jr. (1991). The disuniting of America: Reflections on a multikultural society. Knoxville, TN: Whittle Direct Books. 



\section{DAFTAR ISI}

SAMBUTAN KEPALA BALAI LITBANG AGAMA SEMARANG — iii PENGANTAR EDITOR. — viii PENGANTAR AHLI: Prof. Dr. Wasino, M.Hum. - xiii DAFTAR ISI. — xix

PROLOG: PENGEMBANGAN POTENSI TOLERANSI DAN PERSATUAN BANGSA MELALUI PENDIDIKAN AGAMA BERWAWASAN MULTIKULTURAL

A.M Wibowo. - 1

IMPLEMENTASI PENDIDIKAN AGAMA BERBASIS MULTIKULTURAL PADA SMA DI PROVINSI BALI (Studi pada SMA Surya Wisata di Kabupaten Tabanan Propinsi Bali)

Ali Khudrin. - 23

PENDIDIKAN AGAMA BERBASIS MULTIKULTURAL PADA SMA DI PROVINSI BALI (Studi pada SMAN 1 Tabanan Provinsi Bali)

Wahab. - 53

MENGGALI MULTIKULTURALISME DI SEKOLAH (Studi terhadap SMA Katolik Soverdi Badung)

Siti Muawanah. - 85

PENDIDIKAN AGAMA DALAM BINGKAI BUDAYA MULTIKULTURALIS DI SEKOLAH (Studi Pendidikan Multikultural di SMAN 1 Kuta)

Umi Muzayanah. - 115 
PENDIDIKAN AGAMA BERWAWASAN MULTIKULTURAL PADA SMA SWASTA DI KABUPATEN KLUNGKUNG (Studi pada SMA Pariwisata Saraswati Kabupaten Klungkung) A.M. Wibowo. - 149

IMPLEMENTASI PENDIDIKAN AGAMA BERBASIS MULTIKULTURAL DI SMA NEGERI I SEMARAPURA, KLUNGKUNG, BALI.

Mukbtaruddin. - 185

IMPLEMENTASI PENDIDIKAN AGAMA BERBASIS MULTIKULTURAL DI SMA LAB. UNDIKSHA SINGARAJA PROVINSI BALI

Abmad Muntakbib. - 217

IMPLEMENTASI PENDIDIKAN AGAMA BERBASIS MULTIKULTURAL DI PROVINSI BALI (Studi pada SMA Negeri 1 Singaraja Kabupaten Buleleng)

Mulyani Mudis Taruna 245

IMPLEMENTASI PENDIDIKAN AGAMA BERWAWASAN MULTIKULTURAL DI SMA TAMANRAMA DENPASAR BALI

Yusriati. - 279

EPILOG: PENDIDIKAN AGAMA BERWAWASAN MULTIKULTURAL

Yustiani S.. - 315

BIODATA PENULIS. - 331 